\title{
PERBANDINGAN TINGKAT KEBUGARAN JASMANI SISWA SEKOLAH MENENGAH PERTAMA NEGERI DATARAN TINGGI DAN DATARAN RENDAH (DAERAH PESISIR)
}

\author{
Hegen Dadang Prayoga ${ }^{1}$ \\ Amalia Barikah ${ }^{2}$ \\ hegen.dadang.prayoga@gmail.com \\ Universitas Islam Kalimantan Muhammad Arsyad Al Banjari
}

\begin{abstract}
Abstrak
Penelitian ini dilatar belakangi oleh perbedaan topografi, suhu, kadar oksigen dan pola hidup masyarakat pada daerah dataran tinggi dan daerah pesisiri. Tujuan penelitian ini untuk mengetahui apakah terdapat perbedaan tingkat kebugaran jasmani siswa SMP yang tinggal di daerah dataran tinggi dan di daerah pesisir. Metode penelitian yang digunakan adalah metode expostfacto. Instrumen yang digunakan adalah Tes Kebugaran Jasmani Indonesia (TKJI) untuk siswa SMP. Adapun yang menjadi populasi dalam peneltian ini adalah siswa putra kelas VII-IX di SMPN 4 Pelaihari dan siswa kelas VII-IX di SMPN 1 Takisung. Sampel dalam penelitian ini adalah 20 siswa putra dari SMPN 4 Pelaihari dan 20 siswa dari SMPN 1 Takisung. Teknik sampling yang digunakan adalah cluster random sampling. Penelitian ini memakai analisis statistik yaitu analisis uji t (uji hipotesis). Hasil dari analisis data dalam pengujian hipotesis di dapat hasil t-hitung > t-tabel yaitu (2.02)> 0,05, karena t- hitung $>\mathrm{T}$ tabel. Maka, Ho di terima. Dengan demikian dapat disimpulkan bahwa ada perbedaan tingkat kebugaran jasmani yang signifikan antara siswa SMP yang tinggal di daerah dataran tinggi dan siswa SMP yang tinggal di daerah Pesisir.
\end{abstract}

Kata Kunci : Kebugaran Jasmani, Daerah Dataran Tinggi, Daerah Dataran rendah

\begin{abstract}
This research was motivated by differences in topography, temperature, oxygen levels and lifestyle of people in the highlands and coastal areas. The purpose of this study was to determine whether there were differences in physical fitness levels of junior high school students living in highland areas and in coastal areas. The research method used is the ex post facto method. The instrument used was the Indonesian Physical Fitness Test (TKJI) for junior high school students. The population in this study are male students of class VII-IX at Pelaihari 4 Public Middle School and VII-IX class students at Takisung 1 Public Middle School. The sample in this study were 20 male students from Pelaihari 4 Junior High School and 20 students from Takisung 1 Public Middle School. The sampling technique used is cluster random sampling. This study uses statistical analysis, namely t test analysis (hypothesis testing). The results of data analysis in testing the hypothesis can be obtained t-count>t-table that is (2.02)>0.05, because t-count> T table. So, Ho was accepted. Thus it can be concluded that there is a significant difference in the level of physical fitness between junior high school students living in highland areas and junior high school students living in the coastal area.
\end{abstract}

Keywords : Physical Fitness, Highlands Area, Lowland Region

Dipublikasikan Oleh :

UPT Publikasi dan Pengelolaan Jurnal

Universitas Islam Kalimantan Muhammad Arsyad Al-Banjari Banjarmasin 


\section{PENDAHULUAN}

Provinsi Kalimantan Selatan dengan ibu kotanya Banjarmasin terletak di sebelah selatan pulau Kalimantan dengan batas-batas: sebelah barat dengan propinsi Kalimantan Tengah, sebelah timur dengan Selat Makasar, sebelah selatan dengan Laut Jawa dan di sebelah utara dengan propinsi Kalimantan Timur. Kalimantan Selatan adalah sebuah provinsi yang terletak di pulau Kalimantan, Kalimantan Selatan memiliki total luas 37.377.53 KM2 secara geografis Kalimantan Selatan berada di bagian tenggara pulau Kalimantan, memiliki kawasan dataran rendah di bagian barat dan pantai timur, serta dataran tinggi yang dibentuk oleh pegunungan meratus di bagian tengah, artinya dilihat dari segi geografis Kalimantan Selatan terbagi menjadi dua daerah pertinggal, yaitu dataran tinggi dan dataran rendah. Daerah dataran rendah adalah hamparan luas tanah dengan tingkat ketinggian yang diukur dari permukaan laut adalah relatif rendah, sedangkan dataran tinggi adalah dataran yang terletak pada ketinggian di atas $700 \mathrm{~m}$ diatas permukaan laut. Kalimantan Selatan merupakan salah satu Provinsi yang mencalonkan diri menjadi tuan rumah Pekan Olahraga Nasional (PON) 2024, ini adalah salah satu dasar bahwa pemerintah daerah, masyarakat dan pelaksana kegiatan olahraga sangat mendukung dengan suksesnya olahraga di Kalimantan Selatan.

Provinsi Kalimantan Selatan terdapat Kabupaten Tanjung, Kandangan, Tanah Laut yang berada di derah dataran tinggi dan terdapat banyak sekali sekolah di wilayah tersebut. Lingkungan anak didik berkaitan dengan letak geografisnya sangat beragam. Hal tersebut disebabkan karena di wilayah tersebut berada pada daerah yang kurang rata, tentunya aktivitas masing - masing anak didik di daerah dataran tinggi dan dataran rendah juga berbeda. Secara nyata di lapangan, anak-anak di dataran tinggi lebih banyak aktivitasnya, karena tuntutan medan yang tidak rata, penuh dengan jalan yang naik turun bukit akan memaksa anak didik untuk menempuhnya dengan berjalan kaki setiap hari menuju ke sekolah. Disamping itu kondisi tersebut tentunya tidak bisa ditempuh dengan alat transportasi untuk menuju ke sekolah. Untuk itu diperlukan kondisi kebugaran jasmani yang baik untuk mulai awal dari berangkat ke sekolah hingga pulang kembali ke rumah. Kebugaran jasmani yang baik mutlak harus dimiliki oleh setiap siswa. Orang yang bugar orang yang berpandangan sehat, cerah terhadap kehidupannya, baik untuk masa sekarang maupun masa depannya dan memiliki interaksi sosial yang baik dengan lingkungan sekitarnya. Selain itu, peran guru juga sangat penting dalam proses tumbuh kembang siswanya disekolah, diantaranya guru harus mengetahui tingkat kebugaran jasmani siswanya, karena kebanyakan guru penjas kurang mengetahui seberapa besar tingkat kebugaran jasmani siswanya.Dengan guru penjas mengetahui tingkat kebugaran jasmani siswanya, maka guru penjas bisa menentukan pembelajaran apa yang cocok dengan kondisi kebugaran siswanya. Berdasarkan uraian tersebut, maka penulis memandang perlu untuk mengadakan penelitian mengenai tingkat kebugaran jasmani siswa di daerah dataran tinggi dan siswa di daerah dataran rendah. Selain itu guru penjas juga dapat mengetahui tingkat kebugaran siswanya, karena selama ini belum pernah diadakan tes kebugaran jasmani untuk siswanya.

\section{METODE}

Desain penelitian ini berkenaan dengan sebuah metode yaitu suatu cara yang berkenaan dengan bagaimana data dan informasi yang diperlukan dalam penelitian tersebut dapat diperoleh. Penelitian yang dilakukan adalah penelitian non- eksperimen. Jenis penelitian ini adalah penelitian perbandingan yaitu suatu penelitian yang membandingkan satu kelompok sampel dengan kelompok sampel lainya berdasarkan variabel atau ukuran-ukuran tertentu.

Metode yang digunakan dalam penelitian ini adalah metode survei karena hanya menggambarkan objek yang terbatas. Objek dalam penelitian ini adalah kebugaran jasmani dan subjek adalah para siswa. Selanjutnya instrumen tes yang digunakan untuk melakukan pengukuran dan pengumpulan data mengenai tingkat kebugaran jasmani adalah tes kesegaran jasmani (TKJI) untuk anak usia 10-12 tahun yang diterbitkan oleh Departemen Pendidikan Nasional Tahun 2009. Sampel adalah sebagian dari jumlah atau karakteristik yang dimiliki oleh populasi (Sugiyono, 2008 : 56). Pada penelitian 
ini digunakan teknik cluster random sampling, yaitu teknik penentuan sampel bila semua anggota populasi digunakan sebagai sampel. Untuk menjadi sampel yaitu adalah siswa kelas VII - IX Putra pada sekolah tersebut dikarenakan untuk kategori SMP termasuk ke dalam tes umur 13-15 tahun yang masingmasing berjumlah 20 orang. Penelitian menggunakan instrumen TKJI (Tes Kebugaran Jasmani Indonesia) (Widiastuti 2015) untuk menjawab hipotesis, berikut butir Tes kebugaran yang digunakan: Untuk putra

1. Lari cepat 50 meter

2. Gantung angkat tubuh selama 60 detik

3. Baring duduk selama 60 detik

4. Loncat tegak/vertical jump

5. Lari jauh 1000 meter

\section{HASIL DAN PEMBAHASAN}

Kebugaran jasmani merupakan kemampuan tubuh seseorang untuk melakukan kegiatan seharihari tanpa menimbulkan kelelahan yang sangat berarti, sehingga tubuh masih memiliki simpanan tenaga untuk mengatasi tambahan beban kerja. Istilah kebugaran jasmani mempunyai makna sebagai tingkat kondisi fisik atau kemampuan fisik seseorang. Lebih jauh istilah kebugaran jasmani dijelaskan oleh Wahjoedi (2009: 58 ) berikut : "'Kebugaran jasmani adalah kemampuan tubuh untuk melakukan tugas dan pekerjaan sehari-hari dengan giat, tanpa mengalami kelelahan yang berarti serta dengan cadangan energi yang tersisa ia mampu menikmati waktu luang dan mampu menghadapi hal-hal yang darurat dan tidak terduga sebelumnya"'.

Kebugaran jasmani statis adalah keadaan seseorang yang bebas dari suatu penyakit (sehat). Kebugaran jasmani dinamis merupakan kemampuan untuk bekerja secara efisien yang tidak memerlukan suatu ketrampilan (berjalan, melompat). Kebugaran jasmani motoris adalah kemampuan untuk melakukan aktivitas secara efisien dengan memerlukan ketrampilan (pemain basket harus mampu berlari cepat dengan mendribel bola). Dari ulasan di atas dapat disimpulkan bahwa kebugaran jasmani merupakan suatu kemampuan manusia untuk melakukan kegiatan sehari-hari tanpa mengalami kelelahan yang berarti dan masih memiliki cadangan energi untuk melakukan aktifitas yang lain.

Komponen-Komponen Kebugaran Jasmani

Istilah kebugaran jasmani dijelaskan secara tegas dan dapat dinyatakan bahwa kebugaran jasmani memiliki peranan yang penting dalam kegiatan sehari hari, sehingga semua orang sangat memerlukannya. Oleh karena itu dibutuhkan kondisi fisik yang prima, atau setidaknya melakukan kegiatan olahraga yang teratur guna menjaga atau meningatkan kebugaran jasmani. Komponen kebugaran jasmani yang terkait dengan kesehatan adalah :

Kekuatan otot adalah kemampuan seseorang untuk mengerahkan daya semaksimal mungkin untuk mengatasi sebuah tahanan.

Daya tahan otot adalah kemampuan sekelompok otot untuk mengerahkan daya maksimum selama periode waktu yang relatif lama terhadap sebuah tahanan yang lebih ringan dari beban yang bisa digerakan oleh seseorang.

Kekuatan otot adalah kemampuan seseorang untuk mengerahkan daya semaksimal mungkin untuk mengatasi sebuah tahanan.

Daya tahan otot adalah kemampuan sekelompok otot untuk mengerahkan daya maksimum selama periode waktu yang relatif lama terhadap sebuah tahanan yang lebih ringan dari beban yang bisa digerakan oleh seseorang.

Kemampuan aerobic adalah Kemampuan jantung, paru-paru, dan pembuluh darah dalam menggunakan oksigen dan memanfaatkannya untuk menjadi sebuah tenaga yang dapat digunakan untu aktivitas sehari-hari dalam waktu yang lama.

Fleksibilitas adalah Rentang gerakan yang mungkin dilakukan pada sendi tertentu atau kemampuan untuk menggerakkan otot dan sendi dalam berbagai gerakan.

Komponen kebugaran jasmani yang terkait dengan performa adalah : koordinasi adalah perpaduan gerak dari dua atau lebih persendian, yang satu sama lainya saling berkaitan dalam 
menghasilkan suatu ketrampilan gerak.

Agility adalah kemampuan seseorang untuk dapat mengubah arah dengan cepat dan tepat pada waktu bergerak tanpa kehilangan keseimbangan.

Kecepatan Perbandingan antara jarak dan waktu untuk bergerak dalam waktu yang singkat.

Power Kemampuan untuk mengerahkan upaya eksploif (mendadak) semaksimal mungkin.

Keseimbangan adalah kemampuan untuk mempertahankan tubuh dalam posisi kesetimbangan maupun dalam keadaan statik atau dinamik, serta menggunakan aktivitas otot.

Seperti dibahas pada halaman sebelumnya bahwa kebugaran jasmani dibagi dalam dua jenis, menurut Wahjoedi (2009: 59) Kebugaran jasmani dapat dibagi dalam dua jenis, yaitu kebugaran jasmani yang berhubungan dengan kesehatan dan kebugaran jasmani yang berhubungan dengan ketrampilan gerak, dan masing-masing kebugaran jasmani memiliki komponen-komponen yang menunjang kebugaran jasmani itu sendiri. Kebugaran jasmani yang berhubungan dengan kesehatan sangat diperlukan oleh setiap orang untuk melakukan aktivitas sehari-hari dengan baik. Tidak terkecuali dengan anak- anak usia sekolah dasar yang membutuhkannya untuk masa pertumbuhan dan proses pembelajaran baik di sekolah maupun kegiatan di luar sekolah.

Tabel 1. Hasil tes di daerah Dataran Rendah

\begin{tabular}{|c|c|c|c|c|c|}
\hline \multicolumn{6}{|c|}{ DATARAN RENDAH } \\
\hline NAMA & $\begin{array}{l}\text { Sprit } 50 \\
\text { Meter/ detik }\end{array}$ & Pull-Up & Shit-Up & $\begin{array}{l}\text { Vertical } \\
\text { Jump/cm }\end{array}$ & $\begin{array}{l}\text { Lari } \\
\text { Menengah } \\
\text { 1000meter/ } \\
\text { menit }\end{array}$ \\
\hline Ahmad Saiful Rahman & 6.95 & 12 & 39 & 49 & 03.40 \\
\hline Bagas Ary Mukti & 6.87 & 14 & 28 & 51 & 3,54 \\
\hline Bai Dhowi & 8.71 & 14 & 22 & 66 & 03.40 \\
\hline Erwin & 6.95 & 12 & 40 & 55 & 03.45 \\
\hline Giyanur & 7.15 & 11 & 33 & 67 & 03.20 \\
\hline Hans Febryan Tangaguling & 8.56 & 14 & 27 & 47 & 03.23 \\
\hline Imam Zainal Abidin & 7.89 & 13 & 35 & 37 & 03.43 \\
\hline Jesen Maulani & 7.40 & 15 & 39 & 54 & 03.30 \\
\hline M. Khairul Iman & 7.35 & 9 & 25 & 44 & 03.54 \\
\hline M. Rafly & 6.95 & 10 & 27 & 47 & 04.30 \\
\hline Muhammad Ikhsan & 7.76 & 9 & 39 & 56 & 04.10 \\
\hline Muhammad Ikbal & 7.50 & 12 & 38 & 48 & 03.43 \\
\hline M. Nor Afdilah Firdaus & 8.53 & 10 & 25 & 55 & 03.51 \\
\hline Nadjil Ilham & 7.98 & 6 & 19 & 43 & 03.56 \\
\hline Rahmatillah & 8.30 & 9 & 27 & 45 & 04.17 \\
\hline Ramadhan & 7.50 & 12 & 20 & 33 & 04.08 \\
\hline Repo Agustio & 8.60 & 10 & 25 & 51 & 03.56 \\
\hline Subhan Maulana & 6.60 & 8 & 20 & 57 & 03.52 \\
\hline Ari Saputra & 7.40 & 6 & 19 & 47 & 03.38 \\
\hline Diyan Ainor Rizky & 8.75 & 18 & 40 & 51 & 03.56 \\
\hline
\end{tabular}


Tabel 2. Hasil tes di daerah Dataran Tinggi

\begin{tabular}{|c|c|c|c|c|c|}
\hline \multicolumn{6}{|c|}{ DATARAN TINGGI } \\
\hline NAMA & $\begin{array}{lr}\text { Sprit } & 50 \\
\text { Meter/ detik }\end{array}$ & Pull-Up & Sith-Up & $\begin{array}{l}\text { Vertical } \\
\text { Jump }\end{array}$ & \begin{tabular}{|l} 
Lari \\
Menengah \\
1000meter/ \\
menit
\end{tabular} \\
\hline Ahmad & 6.50 & 17 & 39 & 55 & 03.30 \\
\hline Amat Suhardi & 6.87 & 14 & 28 & 49 & 3,03 \\
\hline Ansyari Rahman & 6.43 & 15 & 22 & 66 & 03.40 \\
\hline Aulia Ramadhani & 6.95 & 16 & 40 & 65 & 03.45 \\
\hline Ilham Kurniawan & 7.15 & 11 & 33 & 67 & 03.20 \\
\hline Irvan Hafiz Ilyas & 8.56 & 14 & 27 & 70 & 03.23 \\
\hline M. Arizal & 7.89 & 13 & 35 & 56 & 03.43 \\
\hline M. Fauzian Permana & 7.40 & 16 & 39 & 54 & 03.30 \\
\hline Muhammad Adrianor & 7.35 & 14 & 25 & 44 & 03.08 \\
\hline Muhammad Alpianoor & 6.95 & 10 & 27 & 47 & 03.11 \\
\hline Muhammad Deri & 6.35 & 9 & 39 & 56 & 04.10 \\
\hline Muhammad Padli & 7.50 & 15 & 38 & 58 & 03.43 \\
\hline M. Surya Wira Yunior & 8.53 & 14 & 25 & 55 & 03.51 \\
\hline M. Ziqro Fuadi & 7.98 & 6 & 19 & 67 & 03.57 \\
\hline Radia Salam & 8.30 & 9 & 27 & 66 & 04.13 \\
\hline Restu Panggeh Saputra & 7.50 & 12 & 20 & 58 & 04.05 \\
\hline Riendy Dwika Novianor & 6.40 & 10 & 25 & 59 & 03.56 \\
\hline Roy Felix Nugroho & 6.60 & 8 & 20 & 60 & 03.51 \\
\hline Rudiansyah & 7.40 & 6 & 19 & 57 & 03.38 \\
\hline Septian Tri Nugroho & 6.20 & 18 & 40 & 58 & 03.29 \\
\hline
\end{tabular}


Deskripsi Data Penelitian

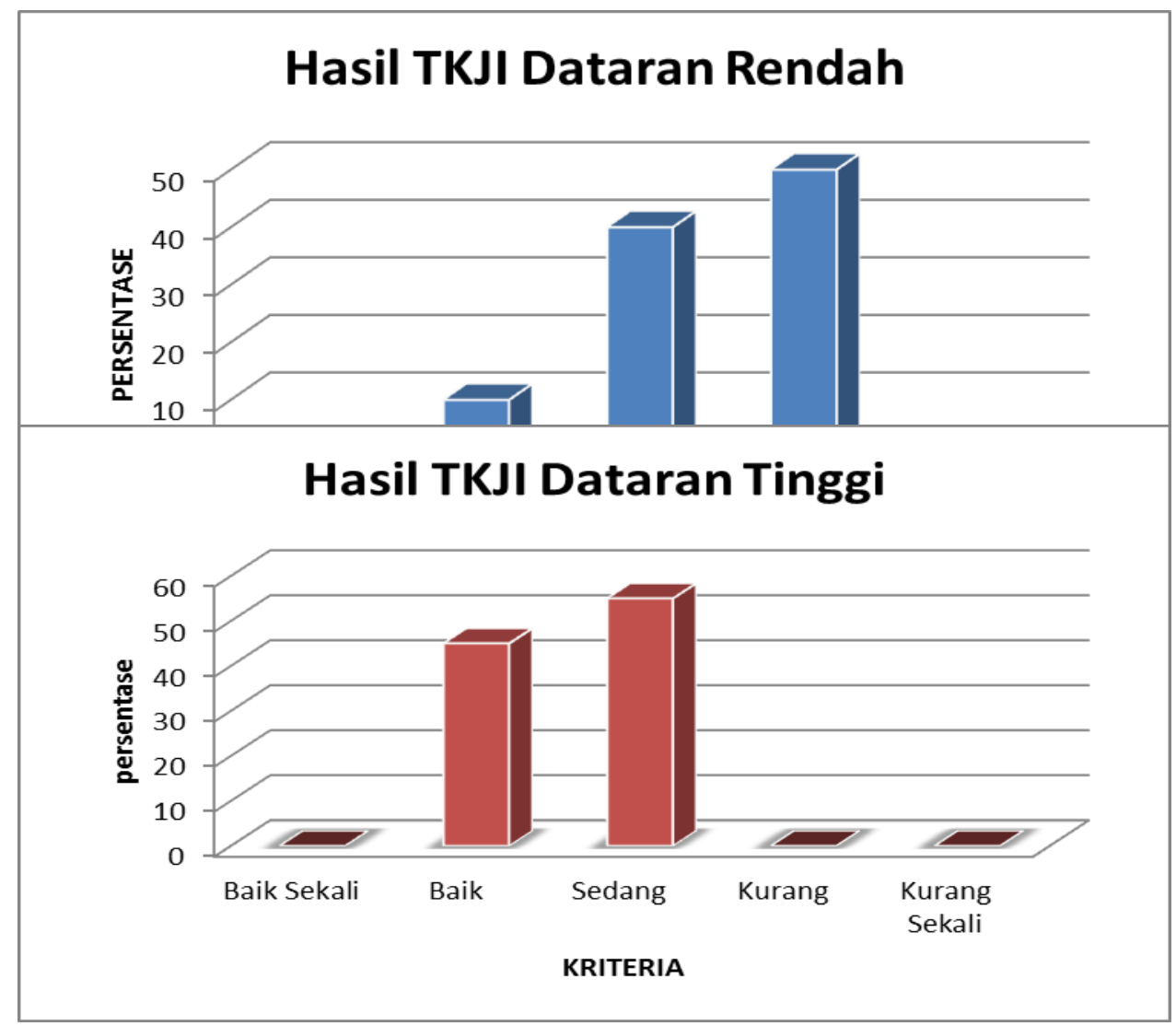

Deskripsi Hasil Penelitian

Hasil Tes Kesegaran Jasmani Indonesia peserta didik di SMP Negeri 1 Tangkisung jenis kelamin putra dengan klasifikasi baik sekali (0\%), klasifikasi baik (45\%), klasifikasi sedang 1 (55\%), klasifikasi kurang $3(0 \%)$, klasifikasi kurang sekali 1(0\%). Sedangkan peserta didik di SMP Negeri 4 Pelaihari dengan klasifikasi baik sekali (0\%), klasifikasi baik (10\%), klasifikasi sedang 1 (40\%), klasifikasi kurang $2(50 \%)$, klasifikasi kurang sekali $1(0 \%)$.

\begin{tabular}{|r|c|r|r|r|}
\hline \multirow{2}{*}{ No } & \multicolumn{5}{|c|}{ HASIL } \\
\cline { 2 - 5 } & Dataran Tinggi & Dataran Rendah & T Score & TScore \\
\hline 1 & 19 & 17 & 56.83 & 59.92 \\
\hline 2 & 20 & 12 & 62.30 & 40.84 \\
\hline 3 & 17 & 14 & 45.90 & 48.47 \\
\hline 4 & 16 & 15 & 40.44 & 52.29 \\
\hline 5 & 17 & 12 & 45.90 & 40.84 \\
\hline 6 & 19 & 16 & 56.83 & 56.11 \\
\hline 7 & 18 & 15 & 51.37 & 52.29 \\
\hline 8 & 20 & 17 & 62.30 & 59.92 \\
\hline
\end{tabular}

Dipublikasikan Oleh :

UPT Publikasi dan Pengelolaan Jurnal

Universitas Islam Kalimantan Muhammad Arsyad Al-Banjari Banjarmasin 


\begin{tabular}{|r|l|l|l|l|}
\hline 9 & 16 & 16 & 40.44 & 56.11 \\
\hline 10 & 16 & 20 & 40.44 & 71.37 \\
\hline 11 & 18 & 13 & 51.37 & 44.66 \\
\hline 12 & 17 & 13 & 45.90 & 44.66 \\
\hline 13 & 17 & 12 & 45.90 & 40.84 \\
\hline 14 & 16 & 15 & 40.44 & 52.29 \\
\hline 15 & 17 & 11 & 45.90 & 37.02 \\
\hline 16 & 20 & 12 & 62.30 & 40.84 \\
\hline 17 & 17 & 13 & 45.90 & 44.66 \\
\hline 18 & 20 & 20 & 62.30 & 71.37 \\
\hline 19 & 14 & 13 & 29.51 & 44.66 \\
\hline 20 & 21 & 12 & 67.76 & 40.84 \\
\hline$\Sigma$ & 355 & 288 & 1000 & 1000 \\
\hline$\dot{X}$ & 17.75 & 14.4 & 50 & 50 \\
\hline$s d$ & 1.83 & 2.62 & 10.01 & 10.01 \\
\hline$>$ & 21 & 20 & 67.76 & 71.37 \\
\hline$<$ & 14 & 11 & 29.51 & 37.02 \\
\hline
\end{tabular}

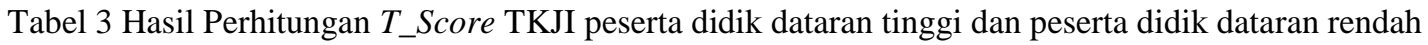

Berdasarkan tabel 3 untuk T-Score peserta didik dataran tinggi didapat skor tertinggi 67.76 dan skor terendah 29.51 diperoleh rata-rata 50 dan standar deviasi 10.01. Untuk $T$-Score peserta didik dataran rendah didapat skor terbaik 71.37 dan skor terendah 37.02 diperoleh rata-rata 50, dan standar deviasi 10,01 .

\section{PENUTUP}

\section{Kesimpulan}

Penelitian ini yaitu kita dapat mengetahui secara bersama - sama dari hasil penelitian bagaimana keadaan fisik pada siswa Sekolah Menengah Pertama (SMP) di dataran tinggi dan dataran rendah. Dari keseluruhan sampel siswa putera Sekolah Menengah Pertama Negeri 4 Pelaihari (daerah dataran tinggi Pegunungan) memiliki tingkat kebugaran jasmani yang rata - rata adalah baik sedangkan Sekolah Menengah Pertama Negeri 1 Tangkisung (dataran rendah atau pesisir) memiliki hasil tes tingkat kebugaran jasmani yang cukup kurang.

\section{Saran}

Dengan adanya penelitian ini maka akan terlihat dari beberapa kekurangan yang terjadi agar dapat ditinjau kembali untuk melakukan budaya berolahraga terutama peningkatan kegiatan fisik pada siswa yang ada di dataran rendah sehingga meningkatkan prestasi olahraga pada dataran rendah yang dapat membangkitkan nama daerah serta kabupaten dalam bidang olahraga.

Dipublikasikan Oleh :

UPT Publikasi dan Pengelolaan Jurnal

Universitas Islam Kalimantan Muhammad Arsyad Al-Banjari Banjarmasin 


\section{REFERENSI}

Arikunto, Suharsimi. (2010). Prosedur Penelitian: Suatu Pendekatan Praktik. Jakarta: PT Rineka Cipta Departemen Pendidikan Nasional. (2009). Tes Kesegaran Jasmani Indonesia. Jakarta: Depdiknas.

Giriwijoyo, Santoso .2007. Ilmu Kesehatan Olahraga (Sport Medicine). Fakultas Pendidikan Olahraga dan Pendidikan UPI. Bandung.

Kemendiknas. (2010). Tes Kesegaran Jasmani Indonesia. Jakarta: Pusat Pengembangan Kualitas Jasmani Marwanto. (2000). „", Tingkat Kebugaran jasmani Siswa SD di Kecamatan Seyegan ${ }^{\text {eece }}$. Skripsi. Yogyakarta: UNY.

Muhajir. (2010). Pendidikas Jasmani Olahraga dan Kesehatan. Jakarta: Erlangga

Pekik, Djoko Irianto. (2012). Pedoman Praktis Berolahraga untuk Kebugaran dan Kesehatan. Yogyakarta: Andi Yogyakarta

Roji. (2009). Pendidikan Jasmani untuk SMP Kelas VII. Jakarta: Erlangga

Rustanti. (2009).,,, Tingkat Kebugaran jasmani Siswa kelas V dan IV SDN 2 Kebukura Kecamatan Sumpuih Tahun Pelajaran 2008/2009 $9^{\text {eee }}$. Skripsi. Yogyakarta: FIK UNY

Sugiyono. (2008). Metode Penelitian Kuantitatif, Kualitatif dan $R \&$ D. Bandung: Alfabeta.

Wahjoedi, 2009. Landasan Evaluasi Pendidikan Jasmani. Jakarta: PT. Raja Grafindo Perkasa 
Dipublikasikan Oleh :

UPT Publikasi dan Pengelolaan Jurnal

Universitas Islam Kalimantan Muhammad Arsyad Al-Banjari Banjarmasin 
